An International Multidisciplinary Double-Blind Peer-reviewed Research Journal

\title{
Clueing in mythical history
}

Kakarla Sai Mitravinda ${ }^{1}$, Pavithra $\mathbf{R}^{2}, 1,2$ Bachelors of Science (Statistics), PSG College of Arts and Science, Bharathiyar University, Coimbatore, TamilNadu, India-641014

\begin{abstract}
Fact is everybody's truth; Fiction is nobody's truth; Myth is somebody's truth." The present paper is about myths and its subsistence till now. Myths have fed the imaginations and souls of humans for thousands of years. It has shown us fascinating heritage of gods, heroes, epic adventures, spooky stories and things that would make an individual question about science. In this article, few concepts have been explored such as, 'myths- its origin , the actual account in history, its major role in today's society, speculation of urban myths and its popularity, famous mythologies, and all its impact on the present society.
\end{abstract}

Keywords: Myths, Mythology, famous, urban legends, Film

\section{Introduction:}

"Myths are early science; the result of men's first trying to explain what they saw around them "said Edith Hamilton. Myths are tales that are based on tradition. Some may have factual origins while some may be completely fictional. But myths are more than mere tales that serve a profound purpose in ancient and modern cultures. These sacred stories explain the experiences of man with the world. Myths are very much relevant to us today like they were with our ancestors. They answer eternal questions and serve as a compass to each generation. For example, the myths of paradise lost give people the hope that they can lead a better life by living virtuously. The myths of golden age gives hope that good leaders will guide them. The hero's quest is a model for young men and women to follow as they accept adult responsibilities. The subjects of myths normally deal with the universal concern of mankind: birth, death, the afterlife, the origin of man, good, the evil and the nature of man. A myth taps into the collective wisdom of man.

Unlike fairly tales, myths are not always optimistic. Essence of myths is such that they are often warnings as promises; as often laments as celebrations. Myths are also persuasive in arts and advertising. Each generation of storytellers add another layer of facts and fictions to the original base and pass it on to the next generation. There are many things in this world which are beyond human thinking capacity and thus we linked them to something that does not exist, something supernatural or is believed to be existed without any proof.

\section{What are myths?}

Myths are folklore genre consisting of narratives or stories that play a fundamental role in a society, such as foundational tales or origin myths. The main characters in myths are usually gods, demigods or supernatural humans. Myths are normally narrated in past format. They are believed to be existed but are not seen today.

But myths are not history. History is the past as it is described in written documents, and the study thereof. Events occurring before written records are considered prehistory. History relates to past events as well as the memory, discovery, collection, organization, presentation, and interpretation of information about these events. Scholars who write about history are called historians. History uses a narrative to examine and analyze a sequence of past events, and objectively determine the patterns of cause and effect that determine them.

But myths though have written evidences do not have materialistic object evidences to support it.

\section{How is mythology connected to myths?}

Mythology is the study and interpretation of sacred tales or fables of a culture or the collection of mythical stories which deal with various aspects of the human condition: good and evil; the meaning of suffering; human origins; the origin of place-names, animals, cultural values, and traditions; the meaning of life and death; the 
An International Multidisciplinary Double-Blind Peer-reviewed Research Journal

afterlife; and the gods or a goddesses. Myths express the beliefs and values about these subjects held by a certain culture. The study of mythology is called mythography.

\section{How many mythologies are there in the world?}

There are thousands of them. Each culture has its own mythology and which they believe it and pass it on to generations. Mythologies all around the world are classified in four.

1. Mythologies by region

2. Mythologies by religion

3. Mythologies by time period

4. Fictional mythologies

\section{What are the most famous among them and why?}

The most famous ones are Abrahamic, Hindu, Norse, West African, Japanese, Sumerian, Greek, Egyptian, Polynesian and Babylonian mythologies. These mythologies are famous because they almost explain what we see around us every day. All the above stated mythologies have historical origin and are very much accepted even in today's world.

The Abrahamic mythology is a collection of Christian, Islamic and Jewish mythologies. Christian mythology is associated with the Christ and the bible, Islamic with the Quran and prophet and the Jewish mythology talks mostly about Judaism. Elements of Jewish mythology have a profound influence on Christian and Islamic mythology and even on world culture. In the Jewish mythology we can find narratives that are present in Christian and Islamic mythologies. Various authors have various narratives in these mythologies to refer to other mythological and allegorical elements found in the Bible or Quran such as the story of Saint George and the Dragon, the stories of King Arthur and his Knights of the Round Table, and the legends of the Parsival. Multiple commentators have classified John Milton's epic poem Paradise Lost as a work of Christian mythology.

The Hindu mythology is narrative gathered from texts like Vedic literature, epics like Mahabharatha, Ramayana, the puranas and also regional literatures. The Hindu people consider these stories factually true and follow certain rituals. We can find a very good mention of this mythology in the Panchathantra and Hitopadesha books.

Norse mythology is of North Germanic people stemming from Norse paganism and continuing after the Christianization of Scandinavia and into the Scandinavian folklore of the modern period. This mythology consists of many stories of deities, beings, heroes derived from sources before and after the pagan period, medieval manuscripts, archeological representations and folk traditions. Some of the Norse gods are Thor, Odin, Freyja, Skadi, Njoror, Heimdallr, Loki and many more.

West Africa is a place that has been dominated by tribal for centuries. Thus, the myths, stories, gods and goddesses are often associated with nature. Most of the mythological stories vanished due to slave trade and thus today have very much less information on this mythology. It is said that most of their gods were associated with five elements of the earth like Abosam, Achimi,Adroa and so on. They linked all the misfortune happening to them with the evil spirits like Ogbanje and Anansi. Unlike western mythology, African myths aren't recounted as single narrative story, nor are there any established corpus of Myth.Instead; myths are embedded and transmitted in ritual practice.

The Japanese mythology is a collection of stories, folktales and beliefs that are found in the Japanese archipelago. Shinto and Budhist culture forms the major part of this mythology.The Kojiki and Nihon Shoki are the old source texts of Japanese mythology. These books talk about the origin of the imperial family saying they 
An International Multidisciplinary Double-Blind Peer-reviewed Research Journal

descended from the sun goddess Amaterasu and her grandson Ninigi. Many deities appear in this mythology .Some names are comparatively long.

Sumer is a part of Mesopotamia now modern day Iraq. Sumerians created a complex civilization with their own language and writing, architecture, arts, astronomy and mathematics. The first Sumerian myth was found in the city of Nippur in form of tablet dating around 5000BC.This mythology claims that at the beginning human like gods ruled over earth. The Sumerian mythology is the interested and most fascinating mythology next to the Greek mythology.

Greek mythology is the most fascinating mythology and is the most known mythology in the world. In ancient Greece, stories about gods, goddesses, heroes and monsters were something like a part of their life. Their myths gave meaning to the world people saw around them. Greek Mythology doesn't have a single source text and was passed on in form of oral tradition. The poet Hesiod's Theogany is the first written cosmogony or origin story by the Greeks. The Theogany tells the story of the universe from a Chaos to being, and details an elaborate family tree of elements, gods and goddesses who evolved from Chaos and descended from Gaia, Ouranos, Pontos and Tartaros.

Egypt had one of the largest and most complex pantheons of gods of any civilization in the ancient world. Egyptians worshipped hundreds of gods and goddesses. Egyptian myths are very absorbing. The story of Osiris is the most famous one. Osiris, one of Egypt's most important deities, was god of the underworld. He also symbolized death, resurrection, and the cycle of Nile floods that Egypt relied on for agricultural fertility. According to the myth, Osiris was a king of Egypt who was murdered and dismembered by his brother Seth. His wife, Isis, reassembled his body and resurrected him, allowing them to conceive a son, the god Horus. He was represented as a mummified king, wearing wrappings that left only the green skin of his hands and face exposed. Each and every god or goddess had their own animal symbols. So, in ancient Egypt not only gods or goddesses but animals were also worshipped.

Polynesia is a region of the Pacific Ocean combining all the widely separated diverse island groups. Most of the Southeast Asian myths can be seen in Polynesia because humans migrated from there to Polynesia 2000 years ago. As time passed they adapted and modified the myths they knew to their new environment. So, in the process they added new characters and events to the traditional myths and legends. Polynesian Mythology placed a great emphasis on the ocean environment. They believed that every living thing consists of a sacred power called Mana and thus made complicated rules to protect it. The most popular character in the Polynesian mythology is Maui. The people living in the pacific didn't venture throughout the world and thus were not very advanced. They still believe these myths and follow this culture whole heartedly.

Babylonian myth records date back to $700 \mathrm{BC}$.They were transcribed in cuneiform on clay tablets and stored in the library of King Ashurbanipal at Ninevah.Apart from this two books were found in form of epics, 'Epic of creation' and the 'Gilgamesh Epic'. The Babylonian mythology is more earth bound and materialistic and thus lacks transcendental quality. The Babylonian gods mostly indulged in eroticism, feasting and fighting.

\section{How Mythology plays a major part in film making:}

A large portion of the movies made in Hollywood concentrated on Greek Mythology. At the point when the main film developed individuals contended that it has assumed control over the job of the novel. Since the time movie producers began to utilize the type of narrating as its structure establishment for films, the progression to take well known books effectively famous and use them in films was a straightforward advance. The adjustment of a novel to a film is a gigantic imaginative undertaking that requests a specific sort of understanding and decisions yet in addition the capacity to reproduce and safeguard the air that has been made. In "O Brother" clearly the movie producers are utilizing adjustment by taking on an old notable story and transforming it into another well known and engaging film. Obviously there are classes under these three different ways in how to break down the movies simply like writing however that isn't the issue here. 
An International Multidisciplinary Double-Blind Peer-reviewed Research Journal

Increasingly significant is the way we see every adjustment of novel to film, every individual has various perspectives and understandings and in this way the comprehension on the adjustment itself is consistently unique. Now and then it is said that film adjustment gets the watcher's consideration just if the watcher has just perused the novel. Once more "O Brother" shows us in any case, despite the fact that the watcher knows nothing about Homers Odyssey the film itself is engaging and maybe due to the beginning content it has incited individuals not exclusively to appreciate the film yet additionally provoked them a while later to go out and read the book. Numerous well known movies have some premise of folklore in them classification film, for example, the western, criminal, war or sci-fi film, which from the outset sight shares nothing for all intents and purpose with the antiquated world, may in any case adjust plots or examples natural from olden times, especially those identifying with chivalrous legend .To make reference to only a couple of motion pictures that have some premise of folklore in them without having the rundown to long: Blade Runner, Neuromancer, The Fifth Element, Aliens, Back to the Future, Batman, Superman, Shane, The Wild Bunch, Narrow Margin, Murder at 1600, Lion King (animation), The Little Mermaid (animation), Hercules (animation and film), The War of the Roses,300,Thor,Meet the Spartans, Percy Jackson,Moana, As Good as It Gets, Excalibur, The Dark Crystal, Merlin, The Star Wars, etc. The rundown may appear to be both clear and astonishing and some become well known and some not. Would could it be that makes some of them so captivating while others don't exactly make the cut? It can't be a result of the on-screen characters, movement or coordinating, the story plot itself is generally the most significant thing if a film is to get the opportunity to endure its underlying fame. The standard hunk, most up to date stars and innovation is regularly insufficient to keep the watcher intrigued while time goes on. A genuine case of a film that despite everything holds some portion of its charm and the colossal impact that it had at its time is O Brother,Where Art Thou.

\section{Mythology and Urban myths-Are they related?}

No, they are not related. Mythology is the study and interpretation of sacred tales or fables of a culture or the collection of mythical stories which deal with various aspects of the human condition. They describe good and bad and at a point make us wonder whether they actually existed. But urban myth is a genre of folklore comprising stories circulated as true, especially as having happened to a friend or family member, often with horrific elements. These legends can be entertainment, but often concern mysterious peril or troubling events, such as disappearances and strange objects.

\section{Is urban myth a hoax?}

Not all urban myths are hoaxes. Every culture has its own urban legend. Some can be very old. Some urban legends have passed through centuries with only minor changes to suit the present situation. But internet urban myths like the bloody Mary, pass it on or you die forward messages, full charge your battery forward messages, and so on are surely hoaxes.

\section{Here are some urban myths that bring Goosebumps whenever one comes across it:}

One thing we must always remember is that all the urban myths are orally passed and we don't have any physical proof for that. For nonbelievers these stories are just a piece of entertainment but for believers it can make them to go the stage of extreme madness. They believe this stories to such an extent that only these things roam in their heads. From the point of view of the discipline of Scientific Research Methodology, no such evidence has been found to attest to the existence in reality or in writing, as it is likely that people encountering such problems are mad and should seek medical assistance. Here are some of the famous urban myths all over the world.

\section{The Curse of $0888-888-888$}

Ever imagined a phone number killing people? The phone number 0888-888-888 has been the number of many people throughout the 2000s, up until now, but every single person who has had the number died. It is 
An International Multidisciplinary Double-Blind Peer-reviewed Research Journal

said that this is a curse which will kill whoever owns the number or tries calling this number. Some owners died of cancer while others died in accident. But don't worry. This number has been suspended by the mobile company and when you try calling this number you will get a message saying, 'out of network coverage. Is 888 the new 666 ?

\section{Jatinga- valley of death for birds}

Jatinga is a village located in the Dima Hasao district in Assam state. Over the last 100 years, thousands of birds have flown to their death over a small strip of land in Jatinga. In only a town of 2500 people, this bizarre incident of fowl death remains largely unexplained, despite studies by most prestigious and famous ornithologists. Although the eerie forces in this area have their sights set on birds rather than humans, the stories are enough to give sleepless nights. The village experiences the unexplained phenomenon of mass bird suicides, with all of them falling dead from the sky between 6:00pm and 9:30pm on moonless nights in the months of September and October.

\section{The Legend of the Blood Countess}

How far will you go to maintain your youth and beauty? Countess Elizabeth Bathory, who lived from 1560 to 1614 in Hungary, is the most prolific female serial killer history will ever remember. She was accused of vampire behavior: Biting the flesh of victims and bathing in their blood as a beauty treatment. She would take her victims underground and subject them to the worst cruelties one could ever imagine. It is believed that she never died and still haunts the castle. Creepy!

\section{Shanthi Devi-A reincarnation tale that even shocked Mahatma Gandhi!}

Shanthi Devi is one of the best cases of children's past life memories ever be recorded. It was investigated by a committee of prominent citizens led by Mahatma Gandhi, who accompanied her to the village of her past-life recollections and recorded what they witnessed.Shanthi Devi when was 5 years old started talking about her past life saying she was Lugdi bai. She even said that she was married and had kids in her past life. When Shanthi grew older she remembered her past life in more detail and clearly described the house she lived, her in laws, how her husband used to look and how difficult her delivery was. The committee investigated Lugdi bai's life and found many things Shanthi described to be true.

Though reincarnation is just a narrative found in mythology, this strange case of Shanthi Devi suggests strong proof of reincarnation. Seems something extraordinary, right?

\section{The Tower of London: Ravens, Ghosts and cursed Jewellery}

From the ghosts that are said to haunt the walls, to the ravens that protect the castle and the city, there are many stories and superstitions surrounding the tower of London.The ravens in the castle are surrounded with a superstition which says that if there are no ravens in the castle, if they get lost or fly away, the crown will fall with Britain in it.Today, the ravens have their wings clipped in a way that allows them to fly, but prevents them from travelling far. A minimum of 6 ravens are kept in the tower guarded by raven master Chris Skaife who has very close bond with the birds. This tower is also said to be haunted by two princes who were murdered by their mother. It is said that one can see two small shadows holding hands and roaming in the night.

The Tower is home to the British Crown Jewels, which are on display at the Jewel House. This includes the Koh-i-Noor diamond which is believed to be cursed.The Koh-i-Noor, which means 'Mountain of Light' in Persian, is a 105 carat diamond and is believed to have been mined in India. A Hindu text from the 1300s reads: "He who owns this diamond will own the world, but will also know all its misfortunes. Only God, or a woman, can wear it with impunity." The history of the stone has been littered with violence; many of the early dynasties that owned the diamond were brief reigns, ending in war. In 1639, the diamond was owned by the Mughal emperor Shah Jahan. His reign ended with his four sons torturing and killing each other. In 1747, 
An International Multidisciplinary Double-Blind Peer-reviewed Research Journal

the Persian King Nadir Shah was assassinated and the diamond passed to his successors. Each one was dethroned and ritually blinded. Similar stories continue through the years. It is believed that the curse only brings bad luck to any man who wears it. Since being ceded to Queen Victoria in 1849, the diamond has only been worn by female members of the British royal family.

\section{Bhangarh-the haunted fort}

Bhangarh is a village situated in Rajgarh Alwar in Rajasthan.It is famous for its historical ruins and is considered to be the most haunted location in India.This place is so haunted that the archeological survey of India has strictly prohibited anyone to enter this fort before sunrise and after sundown.There are in reality two legends about the fort.The famous ones that can be heard from the locals is that a tantric named Singhia fell in love with Princess Ratnavati. He tried to use magic to win over her, but the princess got to know of his evil plans and ordered him killed. Before the tantrik died, he cursed the residents of the fort to die and the village dwellers to remain roofless forever. Certain villages in the city are roofless. Even if a roof is built, it collapses soon after.One can even see dark shadows and eerie sounds in broad daylight.Ghostly!

\section{Aokigahara Forest}

The Aokigohara forest is situated in the foot of Mount Fuji in Japan. The forest is said to be the suicide forest because of dozens of corpses of suicide victims have been found. Legend says that whoever depressed about someon's death or some work which are not so serious to commit suicide comes in the forest will be forced to die and death looks like a suicide. Many ghostly figures and apparitions of the dead victims have been sighted in this forest. So, next time you go to Japan; keep in mind not to visit this forest if you are depressed!

\section{Brown Lady of Raynham Hall}

In 1936, a photographer taking pictures of the 300-year-old Raynham Hall in Norfolk, U.K., captured an image of an apparition floating down the stairs. It's one of the most famous ghost photos ever taken, although some experts believe it was caused by double exposure. The manor, covering an area of 7,000 acres, has a long history of being haunted, and the BBC notes that the ghost may be of Lady Dorothy Townshend, the wife of the second viscount of the estate. She died in 1726, supposedly of smallpox, after having an affair, which her husband Lord Townshend had learned about before her death. She is said to still wander the manor dressed in brown. Spooky!

All the above mentioned stories are ones that passed from mouth to mouth. They neither have any proof to say all these really happened nor a proof saying these are all hoaxes.

\section{Are Urban Myths revealing society's fear?}

Yes. Urban fantasies are odd stories that occasionally get the open creative mind. A few stories like crocodiles amassing the sewers after individuals have flushed the infant reptiles down the latrine, the sitter who gets undermining calls that end up being originating from inside the house, the rodent that gets southern style and served by a quick foot outlet or in a variety, the mouse that has some way or another suffocated in a shut Coca-Cola bottle are silly, yet in a mass society like our own, where stories are generally produced by Hollywood, they just might be the most veritable type of legends. Like customary legends, they are stories created by the aggregate awareness. They offer articulation to the national psyche. When Jan Harold Brunvand, one of the renowned driving specialists on urban legends said that, "the dull contemporary scene is equipped for delivering stunning or astonishing events."

Be that as it may, in these accounts, anything can happen not on the grounds that the world is a supernatural spot rich with amazement but since our reality is so absolutely unnerving. Here, nothing is dependable and no laws of ethical quality oversee. The crocodiles in the sewers presents a picture of a urban 
An International Multidisciplinary Double-Blind Peer-reviewed Research Journal

damnation possessed by mammoths - a picture that may have come straightforwardly from Hades and the River Styx in Greek folklore; The sitter and the man upstairs adventures fears that we are not even safe in our own homes nowadays.; The mouse in the soft drink cautions us of the hazards of an indifferent large scale manufacturing society.Urban legends testify to an overwhelming condition of fear and to a sense of our own impotence within it. That is why there is no accommodation in these stories, any lesson or wisdom imparted. What there is, is the stark impression that our world is anomic. We live in a haunted forest of skyscrapers or of suburban lawns and ranch houses, but there is no one to exorcise the evil and no prince to break the spell.

\section{Conclusion:}

Mythology and folklore are windows to our cultural souls, just as our respective technologies are. Anything that we create and perpetuate presents a connection, both intellectual and visceral, to our origins and our sense of identity and purpose. I would like to conclude by quoting the lines of Ed Kramer and Neil Gaiman,

"We need gods - Thor or Zeus or Krishna or Jesus or, well God - not so much to worship or sacrifice to, but because they satisfy our need - distinctive from that of all the other animals - to imagine a meaning, a sense to our lives, to satisfy our hunger to believe that the muck and chaos of daily existence does, after all, tend somewhere. It's the origin of religion, and also of storytelling - or aren't they both the same thing? As Voltaire said of God: if he did not exist,it would have been necessary to invent him."

"There are only two worlds - your world, which is the real world, and other worlds, the fantasy. Worlds like this are worlds of the human imagination: their reality, or lack of reality, is not important. What is important is that they are there. These worlds provide an alternative. Provide an escape. Provide a threat. Provide a dream, and power; provide refuge, and pain. They give your world meaning."

\section{References:}

Puhvel, Jaan,' Comparative Mythology', United States of America: The Johns Hopkins University Press, 1987.

Sveindís, Sveinsdóttir,’ Mythology to Film’, Hugvísindasvið,University of Iceland,2010

Graziosi, Barbara and Greenwood, Emily, 'Homer in the Twentieth Century: Between World Literature and the Western Canon', Oxford: Oxford UP, 2007

Gabler, Neal,' THE CULTURE : How Urban Myths Reveal Society’s Fears',Los Angeles Times,1995

Brunvard, Jan, 'Encyclopedia of urban legends',ABC Clio,2001

Cayce, Edgar, 'Reincarnation and Karma', Edgar Cayce Foundation,2012

James,M,' Collected Ghost stories',Edward Arnold,1931

Hamilton,Edith,' Mythology:Timeless tales of Gods and Heroes',Little,brown and Company,1942 